\title{
Helicobacter pylori eradication therapy in an area of southeastern Brazil: a cohort study
}

\author{
Alessandro Lisboa da Silva'(®), Rodrigo Siqueira-Batista ${ }^{1}$, \\ Paulo Sérgio Balbino Miguel'(i), Tiago Ricardo Moreira' ${ }^{1}$, \\ Andreia Patrícia Gomes ${ }^{1,11}$
}

\author{
'Universidade Federal de Viçosa, Viçosa, MG, Brasil \\ "Faculdade Dinâmica do Vale do Piranga, Ponte Nova, MG, Brasil
}

\begin{abstract}
The Second and Third Brazilian Consensuses on Helicobacter pylori indicate the combination of a proton pump inhibitor (PPI), amoxicillin, and clarithromycin as the first-line therapy for eradicating this pathogen, but this regimen has been criticized for the recent decrease in its efficacy in several parts of the world. There are little data on the efficacy of $\mathrm{H}$. pylori eradication regimens in the interior of Brazil. OBJECTIVE: To describe the treatments prescribed for the eradication of $\mathrm{H}$. pylori with their respective efficacy rates in a cohort living in the Zona da Mata of Minas Gerais. DESIGN: A retrospective cohort study with treatment-naïve patients known to have gastric infection by $\mathrm{H}$. pylori, residents of the Zona da Mata of Minas Gerais, submitted to eradication therapy of this pathogen in the periods 2007 to 2011, and 2013 to 2016. The $\mathrm{H}$. pylori eradication rates obtained with the prescribed treatments were evaluated as outcomes. RESULTS: We analyzed 5010 medical records from a single health service, with 264 prescriptions for initial treatments to eradicate $\mathrm{H}$. pylori using PPI associated with amoxicillin and clarithromycin for 7 days in 243 cases (88.25\%). The overall efficacy rate of this regimen was 54.07\%, with no differences in efficacy between the two periods analyzed (2007 to 2011: 54.55\%, 2013 to 2016: 53.65, $p=0.892)$ There were no differences in efficacy according to the choice of PPI: Omeprazole-AC7: $52.55 \%$, $\mathrm{OR}=1$ (72 successes out of 137); Lansoprazole-AC7: 44.18\%. OR = 1.399, $p=0.28$ (38 out of 86); and Pantoprazole-AC-7: 60\%, OR $=0.739, p=0.701$ (12 out of 20). CONCLUSIONS: In this cohort, the efficacy rates of the regimens recommended by the Brazilian Consensus on Helicobacter pylori were lower than those previously described in the Brazilian literature, suggesting the need for a revision of the official recommendations.
\end{abstract}

Keywords: Helicobacter pylori; Therapy; Retrospective cohort; Epidemiology; Brazil 


\section{INTRODUCTION}

Helicobacter pylori is a Gram-negative rod when viewed under differential Gram staining. It produces urease and colonizes and infects the gastric epithelium, causing diseases such as chronic gastritis, peptic ulcer disease and gastric cancer (GRAHAM AND DORE, 2016) (specifically, non-cardia adenocarcinoma and gastric mucosa-associated lymphoid tissue lymphoma). This infection is also related to immune thrombocytopenic purpura, refractory iron deficiency anemia, and vitamin B12 deficiency. It is extremely common, affecting approximately $50 \%$ of the world's population (THUNG et al., 2016; SUGANO et al., 2015; MALFERTHEINER et al., 2012; ZAMANI et al., 2018; MALFERTHEINER et al., 2017), with the highest prevalence in regions with poor socioeconomic and sanitary conditions. Today, eradication therapy is indicated for all diagnosed cases of gastric infection by H. pylori (SUGANO et al., 2015; MALFERTHEINER et al., 2017), mainly because this conduct has the potential to reduce the incidence of gastric cancer (FORD, 2015; LEE et al., 2016).

However, eradicating $H$. pylori has not been an easy task as it requires a routine of at least one gastric acid secretion blocking agent and two or three antimicrobial agentes (MALFERTHEINER et al., 2017; MALFERTHEINER et al., 2002; MALFERTHEINER et al., 2007; MALFERTHEINER et al., 2012). The Second and Third Brazilian Consensuses on H. pylori, published in 2005 and 2013, respectively, indicated the triple regimen originally proposed in the first Maastricht Consensus - a protonic pump inhibitor (PPI) associated with amoxicillin or metronidazole and clarithromycin - as the preferred option for the first attempt to eradicate $H$. pylori in the country.

However, this regimen has recently been criticized for its reduced efficacy in various parts of the world. Today, according to the fifth edition of the Maastricht Consensus(MALFERTHEINER et al., 2017), this regimen remains a recommended first-line treatment only where the rate of prevalence of primary resistance of $H$. pylori to clarithromycin is less than $15 \%$, or in locations where studies have 
reported its efficacy in the local population. One such example is the multicenter study by Sanches(SANCHES et al., 2016) which, with a sizable sample and involvement of centers from all regions of Brazil, described a rate of resistance to clarithromycin that was already higher than the threshold beyond which the fifth Maastricht Consensus recommends abandoning triple regimens based on clarithromycin(MALFERTHEINER et al., 2017).

The results of $H$. pylori eradication therapy in the interior of Brazil are little known, mainly because most of the available data relate to patients treated in reference centers in the capitals. This study describes the therapeutic regimens prescribed for the eradication of H. pylori in a cohort residing in the Zona da Mata of Minas Gerais with their respective efficacy rates, thereby contributing information about the treatment of the disease in the interior of Brazil.

\section{METHODS}

The methodology of this study was examined and approved by the Ethics Committee for Research involving Human Beings of the Universidade Federal de Viçosa (CEP-UFV) (CAAE 79804317.2.0000.5153), as required by Resolution 466/2012 of the National Health Council.

This is a retrospective cohort study with the therapeutic regimens prescribed for the first attempt to eradicate $H$. pylori as the exposure variable, and their efficacy as the outcome variable, using two convenience samples from the same population, separated only by one break in time.

Data were collected from the medical records archive of a specialized practice established in the city of Viçosa - MG from 2007, including private patients and those linked to the supplementary health sector, whether referred or nonreferred, all residents of the area covered by the Intermunicipal Health Consortium of the Micro-region of Viçosa (Consórcio Intermunicipal de Saúde da Microrregião de Viçosa), which comprises 10 municipalities in the Zona da Mata of Minas Gerais, 
with a total of 145,731 inhabitants according to the Instituto Brasileiro de Geografia e Estatistica (IBGE) estimate for 2016.

Patients with documented $H$. pylori infection treated to eradicate this pathogen between 2007 and 2011 (Group A) and between 2013 and 2016 (Group $B)$ were included if they had enough information in their medical records to verify efficacy. This verification was performed by applying a rapid urease test associated with histopathological analysis of gastric tissue, performed at least 8 weeks after completion of treatment.

Data from Group A (period from 2007 to 2011) were recorded in handwritten medical records, extracting the data after reading each of the 2234 medical records. Treatments to eradicate $H$. pylori were mentioned in 496 of the records, but the minimum criteria for inclusion in the study were met in only 147. Most of the exclusions were due to a lack of complete information about the outcomes of the prescribed treatments.

Data from Group B (period from 2013 to 2016) were recorded in electronic medical record software and were extracted by keyword searches on the medical evolution text. A total of 2776 medical records were examined, but only 378 of these were found to contain at least one of the keywords (clarithromycin, levofloxacin, Peptulan ${ }^{\circledR}$, Omepramix $^{\circledR}$, Pyloripa $^{\circledR}$, and H Bacter $\left.{ }^{\circledR}\right)$. Of these, 167 met the inclusion criteria of the study. The most frequent reason for non-inclusion was the absence of complete information about the outcome of the prescribed treatments.

Data from the period between 2011 and 2013 were not used because these were stored in electronic medical record software that did not have the function to perform keyword searching on the evolution text.

A database was built for each period analyzed using Microsoft Excel ${ }^{\circledR}$. All the statistical analyses were performed using Epi Info ${ }^{\circledR}$ software, version 7.2.2.2. First, descriptive statistical procedures were applied, with absolute and relative frequencies for the categorical variables and means and medians for the continuous variables, accompanied by their measures of dispersion. Next, the sociodemographic variables available in the two databases were compared, 
seeking to identify statistically significant differences between them. The $X^{2}$ or Fisher's exact test was applied for categorical variables, the Student's t-test for continuous variables of normal behavior, and the Mann-Whitney $U$ test for continuous variables of non-parametric behavior. Finally, the results of treatments prescribed to eradicate $H$. pylori were analyzed, determining the absolute and relative frequencies. Groups submitted to the same treatments but obtained from different databases were compared using the methods described above for investigating whether there were any differences in the results of the two groups. The strength of association between the outcome variable and the explanatory variables was estimated by the odds ratio and the respective $95 \%$ confidence intervals.

\section{RESULTS}

The general characteristics of the two groups are summarized in Table 1. From the data presented, we can infer that both are comparable in terms of age distribution, sex, education, place of birth, and profession.

Table 1 - General characteristics of groups A (2007-2011) and B (2013-2016)

\begin{tabular}{lccc}
\hline & Group A & Group B & p-value \\
\hline AGE & & & \\
Mean (standard deviation) & $50.9(16.25)$ & $52.33(15.17)$ & $0.424^{\mathrm{a}}$ \\
Median (IQR 25-75) & $52(38-63)$ & $54(40-63)$ & \\
Range & $15-86$ & $21-99$ & \\
\hline SEX & $\mathrm{n}(\%)$ & $\mathrm{n}(\%)$ & $0.295^{\mathrm{b}}$ \\
Male & $49(33.56)$ & $60(35.93)$ & \\
Female & $97(66.44)$ & $107(64.07)$ & \\
Total & $146(100)$ & $167(100)$ & \\
\hline EDUCATION & $\mathrm{n}(\%)$ & $\mathrm{n}(\%)$ & \\
Primary or less & $15(32.61)$ & $59(35.76)$ & \\
Secondary complete or incomplete & $11(23.91)$ & $58(35.15)$ & \\
\hline
\end{tabular}

Continuation... 
6 | Helicobacter pylori eradication therapy in an area of southeastern Brazil: a cohort study

\begin{tabular}{|c|c|c|c|}
\hline \multicolumn{4}{|l|}{ Conclusion } \\
\hline & Group A & Group B & p-value \\
\hline Higher complete or incomplete & $20(43.48)$ & $48(29.00)$ & \\
\hline Total & $46(100)$ & $165(100)$ & \\
\hline PLACE OF BIRTH & n (\%) & $\mathrm{n}(\%)$ & $0.512^{b}$ \\
\hline Viçosa & $14(35.89)$ & $48(34.28)$ & \\
\hline CISMIV, except Viçosa & $8(20.51)$ & $47(33.58)$ & \\
\hline Zona da Mata, except CISMIV and Viçosa & $8(20.51)$ & $23(16.43)$ & \\
\hline Minas Gerais, except Zona da Mata & $5(12.82)$ & $10(7.14)$ & \\
\hline Brazil, except Minas Gerais & $3(7.70)$ & $12(8.57)$ & \\
\hline South America, except Brazil & $1(2.57)$ & $0(0)$ & \\
\hline Total & $39(100)$ & $140(100)$ & \\
\hline RESIDENCE & $\mathrm{n}(\%)$ & & \\
\hline Viçosa & $102(83.61)$ & & \\
\hline Other CISMIV municipalities & $18(14.75)$ & & \\
\hline Others & $2(1.64)$ & & \\
\hline Total & $122(100)$ & & \\
\hline MARITAL STATUS & & n (\%) & \\
\hline Married & & $109(65.27)$ & \\
\hline Single & & $31(18.56)$ & \\
\hline Separated & & $11(6.59)$ & \\
\hline Stable union & & $1(0.60)$ & \\
\hline Widow & & $15(8.98)$ & \\
\hline Total & & $167(100)$ & \\
\hline PROFESSION & & & $0.185^{b}$ \\
\hline Retired, without profession, or student & $25(45.45)$ & $70(45.45)$ & \\
\hline Fundamental Level & 5 (9.09) & $23(14.94)$ & \\
\hline Middle Level & $9(16.36)$ & 35 (22.73) & \\
\hline Top Level & $16(29.09)$ & $26(16.88)$ & \\
\hline Total & $55(100)$ & $154(100)$ & \\
\hline
\end{tabular}

Source: Authors (2020)

In Were: $a=p$-value calculated by Student's t-test. $b=p$-value calculated by the $\chi 2$ test 
In Group A, 121 prescriptions for the first treatments to eradicate H. pylori were found; 116 (95.87\%) with 7 days' duration and 5 (4.13\%) with 10 days' duration. The 7-day regimens basically consisted of triple regimens containing a PPI associated with amoxicillin and clarithromycin (110 cases or $94.28 \%$ of the prescribed 7-day regimens) and the others are itemized below:

- omeprazole + furazolidone + clarithromycin (three cases, two successful cases and one failed case)

- omeprazole + amoxicillin + metronidazole (two cases, one successful case and one failed case)

- omeprazole + amoxicillin + levofloxacin (only one failed case).

The five prescribed 10-day treatments were:

- pantoprazole + amoxicillin + clarithromycin (one case, one failed case)

- omeprazole + amoxicillin + levofloxacin (three cases, two successful cases)

- esomeprazole + amoxicillin + levofloxacin (one case, one successful case).

No 14-day therapeutic regimens were prescribed in Group A.

In Group B, 143 prescriptions for first treatments to eradicate H. pylori were found, 132 (92.31\%) with 7 days' duration, 10 with 10 days' duration (6.99\%), and only 1 with 14 days' duration (0.7\%). As observed in Group A, the 7-day regimens consisted basically of triple regimens containing a PPI associated with amoxicillin + clarithromycin (123 cases or $93.18 \%$ of the 7 -day regimens). The remaining 7 -day regimens were:

- omeprazole + amoxicillin + azithromycin (one case, one failed case)

- omeprazole + amoxicillin + levofloxacin (one case, one successful case)

- omeprazole + amoxicillin + clarithromycin + metronidazole (one case, one failed case)

- six treatments with furazolidone + clarithromycin, all without therapeutic success (one with omeprazole, one with pantoprazole, and four with rabeprazole). 
In Group B, we found prescriptions for the following treatments with 10 days' duration:

- omeprazole + amoxicillin + clarithromycin (two cases, one successful case)

- pantoprazole + amoxicillin + clarithromycin (Three cases, one successful case)

- omeprazole + amoxicillin + levofloxacin (two cases, one successful case)

- omeprazole + amoxicillin + metronidazole + levofloxacin (one case, one successful case)

- omeprazole + amoxicillin + clarithromycin + colloidal bismuth subcitrate (one case, one successful case)

- omeprazole + metronidazole + doxycycline + colloidal bismuth subcitrate (one case, one failed case).

The only 14-day regimen prescribed was pantoprazole + furazolidone + clarithromycin (one case, one failed case).

The overall efficacy rate of the first treatment for the eradication of $\mathrm{H}$. pylori was 53.72\% (65 successful cases among 121 treated cases) in Group A and 50.35\% (72 successful cases among 143 treated cases) in Group B, with no statistically significant difference between them $(\mathrm{OR}=1.14,95 \% \mathrm{Cl} 0.704-1.858, \mathrm{p}=0.672)$

When the analysis was restricted to the 7-day regimens containing amoxicillin and clarithromycin, regardless of the PPI employed, there was an overall efficacy rate of 54.55\% (60 out of 110 patients) in Group A and 53.65\% (66 out of 123 patients) in Group B, without a statistically significant difference between these samples at a significance of $0.05(p=0.892)$. (Table 2$)$ 
Table 2 - Results of first treatment for eradication of Helicobacter pylori. Seven-day regimens containing amoxicillin, clarithromycin, and PPIs. Comparisons within the lines

\begin{tabular}{lccccccc}
\hline \multirow{2}{*}{$\begin{array}{c}\text { Regimen } \\
\text { prescribed }\end{array}$} & \begin{tabular}{c} 
Success $\mathbf{n}$ \\
\cline { 2 - 7 }
\end{tabular} & $\begin{array}{c}\text { Failure } \mathbf{n} \\
\mathbf{( \% )}\end{array}$ & $\begin{array}{c}\text { Total } \mathbf{n} \\
\mathbf{( \% )}\end{array}$ & $\begin{array}{c}\text { Success } \mathbf{n} \\
\mathbf{( \% )}\end{array}$ & $\begin{array}{c}\text { Failure } \mathbf{n} \\
\mathbf{( \% )}\end{array}$ & $\begin{array}{c}\text { Total } \mathbf{n} \\
\mathbf{( \% )}\end{array}$ & $\begin{array}{c}\text { p- } \\
\text { value }\end{array}$ \\
\hline OmeAC-7 & $52(57.77)$ & $38(42.23)$ & $90(100)$ & $20(42.55)$ & $27(57.45)$ & $47(100)$ & $0.902^{\mathrm{a}}$ \\
LansAC-7 & $6(37.5)$ & $10(62.5)$ & $16(100)$ & $32(66.66)$ & $16(33.34)$ & $48(100)$ & $0.075^{\mathrm{b}}$ \\
PantAC-7 & $1(33.33)$ & $2(66.67)$ & $3(100)$ & $11(64.7)$ & $6(35.3)$ & $17(100)$ & $0.536^{\mathrm{b}}$ \\
RabeAC-7 & $1(100)$ & $0(0)$ & $1(100)$ & $0(0)$ & $1(100)$ & $1(100)$ & NE \\
EsoAC-7 & $0(0)$ & $0(0)$ & $0(0)$ & $1(50)$ & $1(50)$ & $2(100)$ & NE \\
PPI AC-7 & $0(0)$ & $0(0)$ & $0(0)$ & $2(25)$ & $6(75)$ & $8(100)$ & $N E$ \\
Total & $60(54.55)$ & $50(45.45)$ & $110(100)$ & $66(53.65)$ & $57(46.35)$ & $123(100)$ & $0.892^{a}$ \\
\hline
\end{tabular}

Source: Authors (2020)

In were: Analysis with Pearson's $\chi 2$ (a) and Fisher's exact test (b); Key: NE = not evaluated; Ome = omeprazole; Lans = lansoprazole; Pant = pantoprazole; Rabe = rabeprazole; Eso = esomeprazole; $\mathrm{PPI}=$ proton pump inhibitor; AC-7 = amoxicillin 1 g bid + clarithromycin $500 \mathrm{mg}$ bid for 7 days.

When we analyzed the influence of PPI choice on the efficacy of 7-day regimens containing amoxicillin and clarithromycin, there was no statistically significant difference between subgroups extracted from Group A (lansoprazole vs. omeprazole: $\mathrm{OR}=2.28,95 \% \mathrm{Cl}=0.7629-6.8184, \mathrm{p}=0.14$ and lansoprazole vs. pantoprazole: $\mathrm{OR}=0.83,95 \% \mathrm{Cl}=0.061-11.27, \mathrm{p}=0.89$ ). In Group $\mathrm{B}$, there was a decrease in the chance of failure of $\mathrm{H}$ pylori eradication treatment when omeprazole was used instead of lansoprazole $(O R=0.37,95 \% \mathrm{Cl}=0.1610-0.8523$, $p=0.019$ ). The same was not observed in the comparison between the use of lansoprazole and pantoprazole $(\mathrm{OR}=0.916,95 \% \mathrm{Cl}=0.2869-2.9293, \mathrm{p}=0.83)$. The data volume was insufficient to analyze the influence of second-generation PPIs (rabeprazole and esomeprazole) on the efficacy of the reported triple therapy.

By reanalyzing the influence of the choice of PPI on the efficacy of triple regimens containing amoxicillin and clarithromycin, but by grouping the data of 
the two groups, we found that the statistically significant difference found in the previous analysis disappeared (Table 3).

Table 3 - Effectiveness of triple regimens containing amoxicillin and clarithromycin according to the choice of PPI. Analysis of the two groups combined

\begin{tabular}{lcccccc}
\hline \multicolumn{1}{c}{$\begin{array}{c}\text { Regimen } \\
\text { prescribed }\end{array}$} & \multicolumn{3}{c}{ Groups A and B } & OR & C195\% & $\begin{array}{c}\text { p- } \\
\text { value }\end{array}$ \\
\cline { 2 - 5 } & Failure $\mathbf{n}(\%)$ & Success n (\%) & Total n (\%) & & & \\
\hline OmeAC-7 & $65(47.45)$ & $72(52.55)$ & $137(100)$ & 1 & & \\
LansAC-7 & $48(55.82)$ & $38(44.18)$ & $86(100)$ & 1.399 & $0.813-2.405$ & 0.280 \\
PantAC-7 & $8(40)$ & $12(60)$ & $20(100)$ & 0.739 & $0.272-1.9347$ & 0.701 \\
Total & $121(49.79)$ & $122(50.21)$ & $243(100)$ & & & \\
\hline
\end{tabular}

Source: Authors (2020)

In were: $\mathrm{OR}, 95 \% \mathrm{Cl}$ and $\mathrm{p}$-value calculated by the $\chi 2$ test; Key: Ome = omeprazole; Lans = lansoprazole; Pant = pantoprazole; AC-7 = amoxicillin $1 \mathrm{~g}$ bid + clarithromycin $500 \mathrm{mg}$ bid for 7 days

\section{DISCUSSION}

Our results, the first published for this population, indicate efficacy rates for the first $\mathrm{H}$. pylori eradication treatment regimens of 54.55\% (60 successes in 110 treated) for the period from 2007 to 2011 and 53.65\% (66 successes in 123 treated) in the period from 2013 to 2016, with both analyses being conducted by following standard protocol, without any statistically significant differences being demonstrated between the two periods.

A review of the Brazilian literature included in the PUBMED and LILACS databases was conducted by the authors. There were no date or language restrictions, and the search only included studies with groups of patients treated with PPIs associated with amoxicillin and clarithromycin. The literature review identified 5 prospective studies and 1 retrospective study, involving patients from Bragança Paulista - SP $(n=46)$ (ECCLISSATO et al., 2002), Santo André - SP ( $n=117)$ (BELLELIS et al., 2004), Belo Horizonte $(n=43)$ e Porto Alegre $(n=28)$ (COELHO et al., 2004), Foz do Iguaçu ( $n=54)$ (BERTOLI NETO et al., 2006), and São Paulo (2 
studies, with $n=493$ (FELGA et al., 2010) and $n=50$ (EISIG et al., 2015)), totaling 831 individuals. In these studies, the grouped efficacy rate observed in the analysis by intention-to-treat was $80.14 \%$ (666 successful cases among 831 patients), but with significant heterogeneity between the studies $(I 2=81.7 \%)$.

However, the results of the present study are worse than those previously described for the Brazilian population (efficacy rate $54.08 \%$ vs. $80.14 \%, p<0.001$ ). This is particularly worrying as the patients in this study were treated according to the recommendations of the Brazilian Consensus on Helicobacter pylori (COELHO AND ZATERKA, 2005; COELHO, 2013) in force at the time of prescription.

Some factors that may help explain this difference are examined below:

A significant contingent of patients for whom $\mathrm{H}$. pylori eradication therapy was prescribed was not included in the study because complete data on the verification of $\mathrm{H}$. pylori eradication were not available. To a certain extent, this was because patients did not return for the visit to re-evaluate their clinical condition. It is speculated that these patients who did not return would be more likely to be asymptomatic and to have been successful in their treatments than those who returned, resulting in underestimation of the actual efficacy rate of the proposed treatments.

The main determinants of the success of $H$. pylori eradication therapy are the prevalence of primary resistance of this pathogen to the antimicrobial agents prescribed for its eradication (mainly clarithromycin), the intensity of inhibition of gastric acid production, and patient adherence to the prescribed treatment(MALFERTHEINER et al., 2012; MALFERTHEINER et al., 2017).

The present study did not collect information about the resistance of $H$. pylori to prescribed antimicrobials, but the fact that the results of clarithromycin-based treatments are worse than those previously described in other Brazilian studies suggests the possibility of a higher prevalence of primary resistance of $\mathrm{H}$. pylori to this drug in the population in question. This is plausible as the present study included only patients linked to the supplementary health sector, with higher 
socioeconomic status and therefore with easier access to antimicrobials, particularly macrolides, whether because of easier access to medical appointments or to the possibility of self-medication. On the other hand, patients linked to the Brazilian Unified Health System, not included in this study, have a lower average income than those linked to supplementary care, with less access to medical appointments (SCHEFFER, BIANCARELLI, AND CASSENOTE, 2011) and fewer resources to purchase the medicines themselves, which could result in less intense use of antimicrobials and a less unfavorable bacterial sensitivity profile.

A meta-analysis published in 2012 (McNICHOLL et al., 2012), including 35 randomized and controlled studies involving 5998 patients, found higher rates of eradication of $H$. pylori when the PPI prescribed in the triple regimen was rabeprazole or esomeprazole and not one of the first-generation PPIs (omeprazole, pantoprazole or lansoprazole) (Esomeprazole vs. first-generation PPIs: eradication rate $=82.3 \%$ vs. $77.6 \%, \mathrm{OR}=1.32,95 \% \mathrm{Cl}=1.01-1.73, \mathrm{NNT}=21$ and Rabeprazole vs. first-generation PPIs: eradication rate $=80.5 \%$ vs. $76.2 \%, \mathrm{OR}=1.21,95 \% \mathrm{Cl}=$ $1.02-1.42$, NNT = 23). In this same study, subgroup analysis also showed that the abovementioned benefit was more important in patients with CYP2C19 polymorphism, described as "rapid metabolizer." These patients eliminate firstgeneration PPIs more efficiently than carriers of "slow metabolizer" polymorphism, decreasing the efficacy of these agents in controlling gastric acid secretion, with negative impacts on the efficacy of triple regimens to eradicate $H$. pylori. Thus, second-generation PPIs, which are less affected by this phenomenon, would be interesting options for the treatment of rapid metabolizing patients.

A second meta-analysis, published in 2013(TANG, LI, HU, XIE, AND ZHAI, 2013 ), involving 16 randomized and controlled studies and 3680 patients, without significant heterogeneity, reached conclusions similar to those described in the previously mentioned study, with the polymorphisms of CYP2C19 (homozygous or heterozygous rapid metabolizer and slow metabolizer) having a significant impact on the efficacy of triple therapies for the eradication of $H$. pylori when the chosen 
PPI was omeprazole or lansoprazole, but not when using rabeprazole or esomeprazole. In a Brazilian study derived from the HEROES (MAZZOLENI et al., 2011) trial, originally designed to evaluate the impact of $\mathrm{H}$. pylori eradication on the treatment of patients with functional dyspepsia recruited in Porto Alegre, RS, involving 149 patients selected by randomized sampling, the prevalence of CYP2C19 polymorphisms was described in a Brazilian population: homozygous rapid metabolizer (100 patients or 67.6\%), heterozygous rapid metabolizer (39 patients or 26.3\%), and slow metabolizer (9 patients or 6.1\%) (NABINGER et al., 2016).

In the present study, almost all the treatments prescribed for the first attempt to eradicate $H$. pylori involved the use of first-generation PPIs, with a small number of prescriptions for second-generation PPIs, making any comparative analysis of the efficacy between these two options impossible. In fact, in this study, no statistically significant difference in efficacy was observed between treatments involving omeprazole, lansoprazole, or pantoprazole, which is congruent with the world literature.

This study presents important limitations, mainly due to the non-randomized sample selection and the fact that it is a retrospective study.

The databases evaluated did not provide information on some factors that could influence the success rate of $H$. pylori eradication therapies, especially previous exposure to antimicrobials. Similarly, no special measures were taken to evaluate the adherence of patients to the proposed treatments, and no active search was performed for patients lost to follow-up. All these are factors that may have altered the $H$. pylori eradications rates described.

As we used a convenience sample, with its inherent characteristics, the findings are valid internally but cannot be generalized for the general population. However, given the lack of good quality information on the subject in the population of Viçosa and the surrounding region, the data from this study constitute the best evidence available for the region. 
Finally, there is concern that although the treatments prescribed in the study complied with the recommendations in force during the periods evaluated (the second Brazilian Consensus on Helicobacter pylori in Group A and the third in the case of Group B) in almost all cases, the rates of H. pylori eradication observed fell short of those observed in previous studies. This demonstrates the need for review of official recommendations on the choice of treatment regimens to eradicate $H$. pylori.

\section{CONCLUSIONS}

The results obtained by a single service in the eradication treatment of $H$. pylori in a population linked exclusively to the supplementary health system were described.

The prescribed regimens involved predominantly variations of the triple regimen containing a PPI, amoxicillin, and clarithromycin for the first treatment, with excellent adherence to the prevailing recommendations of the Brazilian Consensus on $\mathrm{H}$. pylori at the time of patient care. The success rates described in Viçosa and the surrounding region were significantly lower than those previously described in other Brazilian studies, without any significant differences being observed for the cases evaluated between 2007 and 2011 and those evaluated between 2013 and 2016.

In view of the recent changes in the Brazilian recommendations on the eradication of $\mathrm{H}$. pylori published by the Fourth National Consensus (COELHO et al., 2018), which increased the recommended treatment time to 14 instead of 7 days and maintained the same drug choices for the first attempt to eradicate $H$. pylori, subsequent studies would be useful to evaluate the effect of these changes in the recommendations. 


\section{REFERENCES}

BELLELIS P, SAMANO EST, NUNES RC, RIBEIRO L DE M, CHEHTER EZ, CATAPANI WR. Efficacy of a triple therapy for Helicobacter pylori eradication in a well-developed urban area in Brazil. Sao Paulo. Med. J. [Internet]. 2004;122(2):73-5. Available from: http://www.scielo.br/scielo.php?script=sci_arttext\&nrm=iso\&lng=pt\&tlng=pt\&pid=S151631802004000200009

BERTOLI NETO JL, LOURENCO LG, BERTOLI CF, ULBRICH FS, SABBI AR, BUENO AG. Evaluation of the efficacy of triple therapy regimen for Helicobacter pylori eradication in gastrectomized patients with gastric adenocarcinoma. Gastric. Cancer. 2006;9(4):291-4.

COELHO LGV, MAGUINILK I, ZATERKA S, PARENTE JM, PASSOS M DO CF, MORAES-FILHO JPP. 3rd Brazilian Consensus on Helicobacter pylori. Arq. Gastroenterol. [Internet]. 2013;50(2):81-96. Available from: http://www.scielo.br/scielo.php?script=sci_arttext\&pid=S0004$28032013000200081 \& \operatorname{lng}=$ en\&tlng=en

COELHO LGV, ZATERKA S. II Consenso Brasileiro sobre Helicobacter pylori. Arq. Gastroenterol. 2005;42(2):128-32.

COELHO LGV, ALVES DE MATTOS Â, FERNANDO C, FRANCISCONI M, DE L, CASTRO P, et al. Eficácia do regime terapêutico empregando a associação de pantoprazol, claritromicina e amoxicilina, durante uma semana, na erradicação do Helicobacter pylori em pacientes com úlcera péptica. Arq. Gastroenterol. [Internet]. 2004 [citado 12 de outubro de 2017]; Available from: http://www.scielo.br/pdf/ag/v41n1/v41n1a14.pdf

COELHO LGV, MARINHO JR, GENTA R, RIBEIRO LT, PASSOS M DO CF, ZATERKA S, et al. Ivth Brazilian consensus conference on Helicobacter pylori Infection. Arq. Gastroenterol. 2018;55(2):97-121.

ECCLISSATO C, MARCHIORETTO MAM, MENDONCA S, GODOY APO, GUERSONI RA, DEGUER M, et al. Increased primary resistance to recommended antibiotics negatively affects Helicobacter pylori eradication. Helicobacter. 2002;7(1):53-9.

EISIG JN, NAVARRO-RODRIGUEZ T, TEIXEIRA ACS, SILVA FM, MATTAR R, CHINZON D, et al. Standard triple therapy versus sequential therapy in Helicobacter pylori eradication: A doubleblind, randomized, and controlled trial. Gastroenterol. Res. Pract. [Internet]. 2015;2015:1-5. Available from: http://www.ncbi.nlm.nih.gov/pmc/articles/PMC4434224/?tool=pubmed

FELGA G, SILVA FM, BARBUTI RC, NAVARRO-RODRIGUEZ TT, ZATERKA S, EISIG JN. Clarithromycin-based triple therapy for Helicobacter pylori treatment in peptic ulcer patients. J. Infect. Dev. Ctries. [Internet]. 2010;4(11):712-6. Available from: http://www.ncbi.nlm.nih.gov/pubmed/21252448 
FORD AC, FORMAN D, HUNT R, YUAN Y, MOAYYEDI P. Helicobacter pylori eradication for the prevention of gastric neoplasia. In: MOAYYEDI $P$, organizador. Cochrane database of systematic reviews [Internet]. Chichester, UK: John Wiley \& Sons, Ltd; 2015. Available from: http://doi.wiley.com/10.1002/14651858.CD005583.pub2

GRAHAM DY, DORE MP. Helicobacter pylori therapy: a paradigm shift. Expert. Rev. Anti Infect. Ther. [Internet]. 2016;7210(April):14787210.2016.1178065. Available from: http://www.tandfonline.com/doi/full/10.1080/14787210.2016.1178065

LEE Y-C, CHIANG T-H, CHOU C-K, TU Y-K, LIAO W-C, WU M-S, et al. Association between Helicobacter pylori eradication and gastric cancer incidence: A systematic review and metaanalysis. Gastroenterology [Internet]. 2016;150(5):1113-1124.e5. Available from: http://linkinghub.elsevier.com/retrieve/pii/S0016508516001207

MALFERTHEINER P, MÉGRAUD F, O'MORAIN C, HUNGIN AP, JONES R, AXON A, et al. Current concepts in the management of Helicobacter pylori infection--the Maastricht 2-2000 Consensus Report. Aliment. Pharmacol. Ther. [Internet]. 2002;16(2):167-80. Available from: http://www.ncbi.nlm.nih.gov/pubmed/11860399

MALFERTHEINER P, MEGRAUD F, O'MORAIN C, BAZZOLI F, EL-OMAR E, GRAHAM D, et al. Current concepts in the management of Helicobacter pylori infection: The Maastricht III Consensus Report. Gut. [Internet]. 2007;56(6):772-81. Available at: http://www.pubmedcentral.nih.gov/articlerender.fcgi?artid=1954853\&tool=pmcentrez\&rende rtype=abstract

MALFERTHEINER P, MÉGRAUD F, O'MORAIN CA, ATHERTON J, AXON ATR, BAZZOLI F, et al. Management of Helicobacter pylori infection - The Maastricht $\{\mathrm{IV} /\}$ Florence Consensus Report. Gut. 2012;61(5):646-64.

MALFERTHEINER P, MEGRAUD F, O'MORAIN CA, GISBERT JP, KUIPERS EJ, AXON AT, et al. Management of Helicobacter pylori infection-the Maastricht V/Florence Consensus Report. Gut [Internet]. 2017;66(1):6-30. Available from: http://gut.bmj.com/lookup/doi/10.1136/gutjnl2016-312288

MAZZOLENI LE, SANDER GB, FRANCESCONI CF MAZZOLENI F, UCHOA DM, DE BONA LR, et al. Helicobacter pylori eradication in functional dyspepsia: HEROES trial. Arch. Intern. Med. [Internet]. 2011;171(21):1929-36. Available from: http://archinte.jamanetwork.com/article.aspx?doi=10.1001/archinternmed.2011.533

MCNICHOLL AG, LINARES PM, NYSSEN OP, CALVET X, GISBERT JP. Meta-analysis: Esomeprazole or rabeprazole vs. first-generation pump inhibitors in the treatment of Helicobacter pylori infection. Aliment. Pharmacol. Ther. 2012;36(5):414-25.

NABINGER DD, MAZZOLENI LE, SANDER GB, MAZZOLENI F, OSÓRIO MC, KLEIN MG, et al. Influence of CYP2C19 on Helicobacter pylori eradication in Brazilian patients with functional dyspepsia. Genet. Mol. Res. Genet. Mol. Res. [Internet]. 2016 [citado 18 de abril de 
2018];15(153). Available from: http://www.funpecrp.com.br/gmr/year2016/vol153/pdf/gmr8734.pdf

SANCHES BS, MARTINS GM, LIMA K, COTA B, MORETZSOHN LD, RIBEIRO LT, et al. Detection of Helicobacter pylori resistance to clarithromycin and fluoroquinolones in Brazil: A national survey Observational Study. World. J. Gastroenterol. 2016;22(33):7587-94.

SCHEFFER, M; BIANCARELLI, A; CASSENOTE A, organizador. Demografia médica no Brasil volume 1: dados gerais e descrições de desigualdades [Internet]. Vol. 1. São Paulo: Conselho, Conselho Regional de Medicina do Estado de São Paulo e Medicina, Federal de; 2011. Available from:

http://www.flip3d.com.br/web/temp_site/edicao-

1415db70fe9ddb119e23e9b2808cde38.pdf

SUGANO K, TACK J, KUIPERS EJ, GRAHAM DY, EL-OMAR EM, MIURA S, et al. Kyoto global consensus report on Helicobacter pylori gastritis. Gut [Internet]. 2015;1-15. Available from: http://gut.bmj.com/lookup/doi/10.1136/gutjnl-2015-309252

TANG HL, LI Y, HU YF, XIE HG, ZHAI SD. Effects of CYP2C19 loss-of-function variants on the eradication of $\mathrm{H}$. pylori infection in patients treated with proton pump inhibitor-based triple therapy regimens: A meta-analysis of randomized clinical trials. PLoS One. 2013;8(4):e62162

THUNG I, ARAMIN H, VAVINSKAYA V, GUPTA S, PARK JY, CROWE SE, et al. Review article: The global emergence of Helicobacter pylori antibiotic resistance. Aliment. Pharmacol. Ther. 2016;43(4):514-33.

ZAMANI M, EBRAHIMTABAR F, ZAMANI V, MILLER WH, ALIZADEH-NAVAEI R, SHOKRI-SHIRVANI J, et al. Systematic review with meta-analysis: the worldwide prevalence of Helicobacter pylori infection. Aliment. Pharmacol. Ther. [Internet]. 2018;47(7):868-76. Available from: http://doi.wiley.com/10.1111/apt.14561.

\section{Authorship contributions}

\section{1 - Alessandro Lisboa da Silva}

Universidade Federal de Viçosa; MsC (Health Sciences), UFV. https://orcid.org/0000-0002-5378-7228 - alessandro.lisboa@ufv.br Contributions: Author of the master's thesis; responsible for performing statistical analysis and writing the article.

\section{2 - Rodrigo Siqueira-Batista}

Universidade Federal de Viçosa e Faculdade Dinâmica do Vale do Piranga; PhD (Public Health), FIOCRUZ. https://orcid.org/0000-0002-3661-1570 - rsbatista@ufv.br Contributions: co-advisor of the master's thesis; responsible for reviewing the article. 


\section{3 - Paulo Sérgio Balbino Miguel}

Universidade Federal de Viçosa; PhD (Microbiology), UFV.

https://orcid.org/0000-0002-6652-366X - psbmiguel@gmail.com

Contributions: co-advisor of the master's thesis; responsible for reviewing the article.

\section{4 - Tiago Ricardo Moreira}

Universidade Federal de Viçosa; PhD (Public Health), UFMG.

https://orcid.org/0000-0002-6606-4942 - tiago.ricardo@ufv.br

Contributions: co-advisor of the master's thesis; responsible for performing statistical analysis and reviewing the article.

\section{5 - Andreia Patrícia Gomes}

Professora do Departamento de Medicina e Enfermagem da Universidade Federal de Viçosa e Faculdade Dinâmica do Vale do Piranga.

https://orcid.org/0000-0002-5046-6883 - andreiapgomes@gmail.com

Contributions: advisor of the master's thesis; responsible for reviewing the article. 